\title{
Feed stock crop options, crop research and development strategy for bioenergy production in India
}

\author{
S. Ramesh* and Balakrishna Gowda \\ Department of Forestry ad Environmental Sciences \\ *Department of Biotechnology, University of Agricultural Sciences, GKVK, Bangalore -560065 (Karnataka), INDIA \\ "Corresponding author. E-mail: ramesh_uasb@ rediffmail.com
}

\begin{abstract}
Soaring prices of fossil-fuels and environmental pollution associated with their use, has resulted in increased interest in the production and use of bio-energy in India. Government of India has made policies to promote the production and use of bio-fuels which have triggered public and private investments in bio-fuel feed stock crop research and development and bio-fuel production. In this paper, efforts have been made to review and discuss various feed stock crop options and crop research and development interventions required to generate feed-stocks to produce required volume of bio-energy to meet projected demand without compromising food/fodder security and potential benefits of bio-fuels in reducing environment pollution and contributing to the energy security in India.
\end{abstract}

Keywords: Agriculture research, Energy security, Bio-diesel, Bio-fuel, Bio-ethanol

\section{INTRODUCTION}

The United Nations (UN) millennium development goals (MDGs) provide a blueprint for improving livelihoods, and preserving natural resources and the environment with 2015 as target date. The UN member states and the world's leading development institutions agreed upon the MDGs. None of them however, have a specific reference to energy security though energy is the fuel of economic prosperity and hence assist in mitigating poverty. The energy is required for consumptive uses (cooking, lighting, heating, and entertainment), social needs (education and health care services), public transport (road, rail and air), industries, and agriculture and allied sectors. India is the sixth largest consumer of energy in the world. Of these, public and goods transport consume bulk of the energy requirement in India. Agriculture production in India also requires sizable volume of energy as it is predominantly an agriculture-based economy. 'Energizing' the agriculture production chain has been an essential feature to achieve food security, considering strong correlation between per capita energy consumption and crop yields in both developed and developing countries. For example, in the Philippines, the productivity of rice $\left(5.8 \mathrm{tha}^{-1}\right)$ grown using mechanized farming is far greater than that grown using traditional farming (1.2 $\mathrm{tha}^{-}$ ${ }^{1}$ ) (www.fao.org). However, agriculture practices in India continue to be based to a large extent on animal and human energy. Nearly $70 \%$ of India's energy requirement is met through fossil-derived crude oil imports. Of late, soaring prices of fossil-fuels and increased environmental pollution associated with their use, has triggered interest in the production and use of alternative environmental friendly and renewable energy sources. Bio-energy is regarded as the best among several alternative renewable energy sources (http://www.fao.org/sd/EGdirect/ EGRE0055.htm.). Bio-energy generated from bio-fuels (liquid form of energy generated from biomass) constitute a sustainable and renewable energy source that may help cope with rising energy pieces, address environmental concerns and offer new income and employment opportunities to farmers and rural communities around the world (Hazell and Pachauri, 2006). Bio-energy already accounts for $10 \%$ of the world energy supplies (Hazell and Pachauri, 2006). The main sources of bio-energy include (i) agricultural residues and waste, (ii) purposegrown crops and (iii) wild vegetation. In their raw form, these sources are usually called as bio-mass. Bio-diesel, bio-ethanol and biomass gasification are the three major bio-energy options, which have huge potential in India to develop as potential energy sources and where investments made would be economical (Parikh and Walia, 2002). Bio-ethanol, produced from starch-/cellulose-/ sugar-based feed stocks, is the most commonly used biofuel world-wide (Ortiz et al., 2006). Bio-diesel, similar in composition to fossil-diesel, is produced by transesterification of oils/fats of plant/ animal origin. Bio-diesel was probably the first of the alternative fuels known to public (Bharadwaj et al., 2007). Government of India has made policies to promote the production and use of biofuels. Bio-fuels are those that do not add to the stock of atmospheric $\mathrm{CO}_{2}$ when burnt. Bio-fuels are produced from 
autotrophic plant forms, which remove $\mathrm{CO}_{2}$ from the atmosphere, give-up the same amount when burnt. In contrast, when fossil fuels are burnt, additional new quantities of $\mathrm{CO}_{2}$ which have been fixed underground in oil deposits for millions of years, will be injected into the atmosphere. The bio-fuels are therefore considered to be ' $\mathrm{CO}_{2}$ neutral' not adding to the $\mathrm{CO}_{2}$ level in the atmosphere.

From industry point of view, governmental policy support to create market forces for bio-fuels, and the availability of land resources, cost-effective bio-mass (feed-stock) energy conversion technologies and byproducts utilization options are important factors (among others) that attract investments in bio-fuel production. Equally important is identifying most suitable feed stock crop/s considering diverse agro-climatic conditions that prevail in India to generate required volume and quality of feedstocks to produce bio-fuel to meet projected demand without compromising food/fodder security. In this article, we review and discuss different feed stock crop options and crop research strategies required for cost-effective production of bio-fuels and the potential benefits of biofuels in contributing to alleviating rural poverty and environment sustainability in India.

\section{CURRENT BIO-FUEL SCENARIO}

Bio-fuels are currently based on the generation of ethanol from sugars or starch derived from vegetative biomass or grain, or bio-diesel from the more direct use of edible and non-edible plant oils and animal fats (Ortiz et al., 2006). Brazil is the shining example for using ethanol (produced from sugarcane juice) either in pure form or as a blend with petrol (gasohol) for fuelling the automobiles. Billions of gallons of bio-ethanol are being produced in Brazil using sugarcane. Ethanol (39 billion liters) accounts for about $90 \%$ of total bio-fuel production in 2005 (www.commodityIndia.com) in the world. Taking a cue from Brazil, India is making concerted efforts to reduce its dependence on oil exporting countries, and pollution levels through policies to produce bio-ethanol and bio-diesel for blending with petrol and fossil diesel, respectively. In India, molasses from sugarcane is being used as feedstock to produce fuel-grade ethanol. Bio-diesel currently is being produced from edible oilseeds from crops such as soybean, rapeseed, sunflower, etc. mostly in European countries. However, India cannot spare edible oilseeds for bio-diesel production, considering large gap between demand and supply of edible oil seeds. Fortunately, biodiesel can also be produced from non-edible oilseeds from native tree species such as pongamia (Pongamia pinnata), neem (Azadichta indica) and Madhuca longifolia and exotic tree/shrubs species such as Simarouba glauca and jatropha (Jatropha curcus).

\section{FEED STOCK CROP OPTIONS AND CROP IMPROVEMENT RESEARCH TO ADDRESS BIO-FUEL NEEDS}

India has plans to double its bio-fuel production within the next 15 years (www.worldwatch.org/node/3893) to achieve energy security. Meeting this target without compromising food and fodder security, requires reorientation of agricultural research, which encompasses careful selection among the existing crop species/ introduction of new crop species and their genetic and production management to improve their energy value. The most promising crop options and the researchable issues need to be addressed for more efficient ethanol and bio-diesel production are discussed here under.

Ethanol : In India, it is mandatory to market 5\% ethanoldoped petrol in nine states and four union territories with plans to increasing the blending proportion to $10 \%$ in a phased manner. In India, much of the fuel-grade ethanol is produced from molasses (Parikh and Walia, 2002). The current level of ethanol production from molasses is just sufficient for 5\% blending. Ethanol required for $10 \%$ blending cannot be produced from molasses alone. Besides this, highly variable supply and cost of molasses, environmental pollution associated with its use for ethanol production have prompted policy makers, administrators and researchers alike to explore alternative feed stocks for ethanol production (Reddy et al., 2005). Sugarcane juice itself is the potential feedstock for ethanol production. Sweet sorghum, cassava and lingo-cellulosic materials such as crop residues of cereals, forest wood thinning, saw dust, paper, etc., are some of the other potential feed stocks for ethanol production in India.

Sugarcane : India is one of the largest sugarcane and sugar producers in the world. Traditionally sugarcane is used for sugar production in India. It can be used for the production of fuel-grade ethanol as well. Sugar is an essential commodity and an important part of the food chain, and demands priority over other alternative uses of sugarcane. Any imbalance between domestic production and demand for sugar would lead to spiraling of prices and other antisocial activities such as hoarding (Bharadwaj et al., 2007). The price of the sugar, which represents the opportunity cost of sugarcane for fuelgrade ethanol production and the price of the crude oil which provides the bench mark against which to compare the cost of fuel-grade ethanol production are the key factors that shape the economic viability of ethanol production from sugarcane juice. India now has a surplus sugar production leading the government to allow limited exports (Bharadwaj et al., 2007). It is predicted that the difference between production and demand persists in 
future. Further increased production will only lead to drastic reduction in sugar price signaling the need for checking the sugar production. This necessitates declaring crushing holiday, which is not in favour of sugarcane growers. A harmonious balance in the demand and supply of sugar, and the ethanol can be brought about if the surplus sugarcane is utilized for the production of ethanol. Such arrangement has become very relevant in the current scenario of economic liberalization and more particularly as a means to correct the surplus sugar production. If $10 \%$ of the sugarcane produce (currently about 280 million tones), i.e. 28 million tones is diverted for only ethanol production, the expected ethanol production@ 975 liters $^{-1}$ is about 2100 million liters (sufficient for $10 \%$ blending with petrol) and the likely sugar production is about 23 million tones @ 9\% sugar recovery (Bharadwaj et al., 2007). At this level of sugar production, the domestic demand is not compromised. Such an arrangement of producing both sugar and ethanol from sugarcane juice is well established in Brazil, the world leader in fuel-grade ethanol production. Out of the total cane available for crushing, $45 \%$ goes for sugar production and rest for the production of ethanol directly from sugarcane juice in Brazil (Moreira, 2006). This provides the sugar industry in Brazil an additional flexibility to adjust its sugar production keeping in view the sugar price in the international market as nearly $40 \%$ of the sugar output is exported.

\section{RELATIVE ECONOMICS OF ETHANOL PRODUCTION FROM MOLASSES AND SUGARCANE JUICE}

It is worthwhile to examine the two commercial options of producing ethanol from sugarcane, (i) from molasses and (ii) from sugarcane juice, in which case no sugar is produced. At the present government procurement price (Rs. 18.75) by oil companies for blending purposes (Bharadwaj et al. 2007), the sugar industry benefits more if it makes ethanol from molasses than from sugarcane juice. This is because, sugarcane juice-based ethanol production cost is about Rs $20 \mathrm{t}^{-1}$ assuming feedstock cost @ Rs. $1000 \mathrm{t}^{-1}$ and including costs of conversion, salary, operational activity, excise duty and marketing. Ethanol price should be at least Rs $22 \mathrm{t}^{-1}$ for sugarcane juice-based ethanol production to be attractive. At this price, the net revenue from ethanol production from molasses and sugarcane juice are comparable. If the ethanol price is $>$ Rs. $22 \mathrm{t}^{-1}$, the net revenue from sugarcane juice-based ethanol production is more than that from molasses. It is still profitable to procure sugarcane @ Rs. $1000 \mathrm{t}^{-1}$ and produce both sugar and fuel-grade ethanol at ethanol price of > Rs. $22 \mathrm{t}^{-1}$. At present many sugar industries are offering very low price for sugarcane on the pretext of surplus sugar production and hence farmers in many states are demanding minimum support price. Considering continuous rise in international crude oil price (currently it is $\$ 135$ barrel $^{-1}$ ), the government procurement price of Rs. 18.75 is not justified; which was fixed when international oil price was much lower than that is prevailing to date. Therefore, it is imperative that the government of India revises the ethanol procurement price between Rs. 22-25, which will encourage sugar industry to divert excess sugarcane for ethanol production. At the same time, constant government vigilance and intervention is essential to check sugar price to maintain a harmonious balance between sugar and ethanol production from sugarcane. Thus, a favorable ethanol pricing policy of the government would help absorb surplus sugar and enable sugar industry to crush excess sugarcane for ethanol production and in turn offer an attractive and stable price to sugarcane farmers. This is definitely a winwin situation for sugarcane growers and sugar industry.

Sweet sorghum: Sweet sorghums, which are similar to grain sorghums but feature more rapid growth, higher biomass production, and wider adaptation and far lower water and other inputs requirements, have great potential for ethanol production. Sweet sorghum, similar to grain sorghum, can be readily cultivated in India as farmers are familiar with grain/fodder sorghum crop cultivation. Sweet sorghum can be grown in nutrient-poor soils where other comparable and competitive crops such as maize cannot be cultivated. The dual-purpose nature of sweet sorghums-they produce both grain and sugar-rich stalks - offers new market opportunities for smallholder farmers and does not threaten food trade for sorghum. Sorghum is being cultivated from time immemorial in India. Incidentally, most of the landraces that are being grown in India during postrainy season are sweet sorghums. The emerging bio-fuel needs, therefore offer expanded markets for sweet sorghum in India. Because sweet sorghum requires less duration and water and has a higher fermentable sugar content than sugarcane (which contains more crystallizable sugars), it is better suited for ethanol production than sugarcane or other feed stock crops. Also, sweet sorghum-based ethanol is cleaner than sugarcane ethanol, when mixed with gasoline. Pilot studies in India have indicated that ethanol production from sweet sorghum is cost-effective (Reddy et al., 2005).

The Indian national sorghum improvement programs and those at International Crops Research Institute for the Semi-Arid Tropics (ICRISAT) located at Patancheru in Andhra Pradesh, India have developed several improved cultivars with high stalk sugar content. A few of these are being tested in pilot studies for sweet sorghum-based ethanol production in India. Research experience at ICRISAT and elsewhere, shows that hybrids are known to produce relatively higher biomass, besides being early and thermo- and photo-insensitive than pure-line cultivar 
under normal as well as abiotic stresses including waterlimited environments. The requirement of photo- and thermo-insensitivity is essential to facilitate plantings at different dates for timely scheduling the supply of sweet sorghum stalks to distilleries for ethanol production (Reddy et al., 2005). The development of sweet sorghum hybrids should therefore receive high priority to produce more feedstock per drop of water and unit of energy invested.

Cassava : Cassava, traditionally a staple food crop for millions of people in Africa and Latin America, is widely cultivated in Asia, mainly for industrial uses. It produces an impressive quantity of root tuber biomass even in lowfertility soils. The root tubers contain a very high starch content (about $70-85 \%$ by dry weight basis), which can be used as feed stock for ethanol production. In the ethanol production process, the harvested roots are readily transformed into dried chips in order to lengthen the storage time of tubers as well as reduce the biomass volume to facilitate easy transportation. Fresh roots can also be used as such to avoid costs of chipping and drying them. To produce ethanol, the starch is first converted into glucose by enzymes and glucose is then fermented to alcohol by yeast (www.cassava.org/News/biofuel/2004/ poster_ethanol1.pdf). The leaves serve as excellent vegetable and are rich in proteins, vitamins and minerals. Recent studies have shown that cassava leaf protein quality is equivalent to that of egg protein (Nassar and Marques, 2006). Cassava provides dietary calories, proteins, vitamins and minerals. India enjoys edaphic and environmental conditions suitable for cassava cultivation. As cassava is dual-purpose (human dietary nutrient and bio-energy source) crop like sweet sorghum, it should be promoted for ethanol production in India.

International Institute of Tropical Agriculture (IITA), Ibadan, Nigeria and International Center for Tropical Agriculture (CIAT), Cali, Colombia have developed early maturing and high yielding cassava varieties with resistance to major diseases and pests. These improved cassava cultivars need to be introduced and tested to identify most suitable cultivars for different agro-climatic zones of India. Also, there is a need to produce cultivars that produce root tubers containing simpler starch molecules that would make the production of bio-ethanol more efficient and competitive by eliminating liquefaction and saccharification, the steps that are additional to those involved in the conversion of ethanol from cereal grains. It has been reported that "sugary" clones exists in Brazil (Carvalhoet al., 2004). Improvement of biomass of these sugary clones will reduce the cost of ethanol conversion through enhanced the efficiency. Currently CIAT is screening the worldwide cassava germplasm collection in search of useful mutants (Ceballos et al.,
2006). Efforts should be made to introduce sugary mutants to India and their biomass should be improved.

\section{SECOND GENERATION ETHANOL}

With the development of bio-catalysts-genetically engineered enzymes, yeasts, and bacteria, it is now possible to produce ethanol (what are called as secondgeneration bio-ethanol) from any plant or plant part known as ligno-cellulose biomass such as crop residues (stovers) of cereal crops. The stover of widely cultivated cereals such as rice, wheat, sorghum, maize, pearl millet, finger millet, etc. serve as excellent feed stocks for ethanol production (Table 1).

Table 1. Potential of ligno-cellulosic biomass for ethanol production.

\begin{tabular}{lc}
\hline Feed stock & Liters ethanol ton \\
\hline Sugarcane bagasse & 500 \\
Rice/wheat/maize/sorghum/pearl & 500 \\
millet stover & \\
Forest thinnings & 370 \\
Hardwood sawdust & 450 \\
Mixed paper & 520 \\
\hline
\end{tabular}

Source: Adapted from Planning commission.nic.in/reports/ genrep/cmtt_bio.pdf

Currently, a few countries with higher ethanol and fuel prices are producing ethanol from ligno-cellulose feed stocks (Badger, 2002). The stovers contain lignin, hemicellulose, and cellulose. The hemi-cellulose, and cellulose are enclosed by lignin (which contains no sugars), making them difficult to reach and convert them into ethanol and hence energy requirement also escalates. Fortunately, brown mid-rib maize mutants (Jorgenson, 1931) and sorghum mutants (Porter et al., 1978) have significantly lower levels of lignin content (by 5 to $50 \%$ in maize stems and by $51 \%$ in stems and by $25 \%$ in leaves in sorghum). Brown mid-rib mutants are also available in sudan grass and pearl millet. Research at Purdue University, West Lafayette, Indiana, USA indicated 50\% higher yield of fermentable sugars from certain maize and sorghum brown mid-rib mutants' stover after enzymatic hydrolysis (www.ct.ornl.gov/symposium/index_files/6Babstracts/ 6B_01.htm). The use of brown mid-rib crop cultivars as feedstocks would therefore reduce the cost of ethanol production, thereby making the price of ethanol competitive to that of fossil fuel. Also, considering that brown mid-rib confer increased rumen digestibility, green fodder and stover from brown mid-rib crop cultivars would serve as excellent source of rumen dry matter requirement. Hence, it is worth making investments on developing high biomass yielding brown mid-rib sorghum, sudan grass, maize and pearl millet hybrids which besides providing cheaper source for bio-fuel production, help meet fodder needs of subsistence farmer. 
North American wild grass : Switch grass (Panicum virgatum), a perennial grass native to the North American prairies, could provide more than 100 billion gallons of bio-ethanol per year. Switch grass can grow on lands incapable of supporting traditional food crops, with $1 / 8^{\text {th }}$ the nitrogen runoff and $1 / 100^{\text {th }}$ the soil erosion of conventional crops (Ortiz et al., 2006). Its deep root system adds organic matter to the soil, rather than depleting it. According to the USA Department of Energy, the switch grass yields about $40 \mathrm{t} \mathrm{ha}^{-1}$ and breeding programs should aim at doubling this yield. Expected ethanol output from switch grass biomass is about 450 liters ton $^{-1}$. (www.prognog.com/driving/ethanol/ switchgrass:_native_american_powerhouse.html).

European grasses : The Miscanthus genus (including giant Chinese grass, silver grass, silver banner grass, maiden grass, and eulalia grass) is receiving attention as a potential source of biomass for bio-fuels. Giant Miscanthus (Miscanthus' giganteus) is a hybrid grass that can grow 4 meters high. Given its rapid growth, low mineral content, and high biomass yield, some European farmers use Miscanthus to produce energy (Ortiz et al. 2006). The biomass from one hectare of Miscanthus can produce about 16,650 liters of ethanol.

Considering high biomass potential of North American switch grass and European grasses, it is worthwhile introducing them to India. Research efforts should be made to evaluate these grasses to identify the agroecological regions best suited for their cultivation and to develop and standardize region-specific crop production technologies to maximize biomass production. Also, these grasses need to be genetically improved further for biomass yield and alter cellulose and lignin composition for cheaper production of ethanol.

Bio-diesel : The non-edible oilseed-borne native tree species crops such as pongamia, neem, kusum, pilu, etc. and exotic tree/shrub species such as Simarouba and Jatropha are potential feed stock crops for bio-diesel production. Though Jatropha is an exotic species, it can be easily grown in India whereas pongamia and neem are native to India. These crops were once hallmark of village life, and can be grown on lands not suitable for food crops cultivation. These crops are easy to establish, quick growing and hardy, and are not browsed by cattle and goats, and thus making them the best candidates for rehabilitating degraded common lands without any protection. Pongamia being a nitrogen fixer also helps build the soil fertility (Wani et al., 2006). The Planning Commission of India has initiated ambitious program of growing jatropha and pongamia on wastelands for biodiesel production. It is estimated that even if $10 \%$ of the total wasteland is brought under cultivation of these species, India can produce about 4-5 million metric tons per annum of bio-diesel, which is about $10 \%$ of the current diesel demand in India (http://www.renewingindia.org/ newsletters/ethanol/current/news_vol1_06.htm).

Oilcakes, the byproducts after extraction of oil from jatropha and neem are rich sources of macro- and micronutrients (planning commission.nic.in/reports/genrep/ cmtt_bio.pdf), and thus serve as an excellent organic fertilizer in crop production. For example application of jatropha and neem cake improved soybean grain productivity by $50-60 \%$ (Wani et al., 2006) and finger millet grain and dry fodder productivity by $40-80 \%$ (unpublished data). Pongamia cake in addition is also a proven nitrification inhibitor in fields enhancing nitrogenuse efficiency of crops by reducing nitrate losses. Jatropha oilcake contains about $61 \%$ protein compared to about $45 \%$ in soybean oilcake (Franscis et al., 2005). However, the presence of toxins/anti-nutrient factors such as phorbol esters, trypsin inhibitors, lectins and phytates (Franscis et al., 2006), renders jatropha oilcake unfit for animal feed. After detoxification, oilcakes are also good sources of feed for milch and draught animals, which are indispensable components of mixed crop-livestock system that prevails in India (Wani et al., 2006). The neem cake besides providing nutrients to plants has proven insecticidal property and thus its use not only empowers farmers to improve soil health but also provide them an eco-friendly means of protecting their crops that support their livelihoods. Developing technologies to make these oilcakes amenable for multiple uses is a key to attract biofuel industries and hence to create large demand for biomass sources.

As Pongamia, neem, Maduca longifolia, Simarouba and Jatropha are still wild tree/shrubs, research is necessary to develop improved cultivars and crop management technologies to maximize seed and oil yields per unit of water and land area. Altering fatty acid composition of the oils of these species is a key to improve bio-diesel productivity. At present a large number of Jatropha and pongamia accessions are being collected by various research organizations in India under bio-diesel network programs funded by the Department of Biotechnology and National Oilseeds and Vegetable Oils Development Board. The collections are being characterized for their oil content and fatty acid composition by Tata Energy Resources Institute (TERI), India. In view of their outbreeding mode of reproduction, large variability in seed yield and oil content between individual plants is observed. For example, per plant seed yield of Jatropha ranges between $200 \mathrm{~g}$ to $>2 \mathrm{~kg}$ (Sharma et al., 1997). Therefore, the appropriate kind of planting material (vegetative propagation/tissue culture seedlings) to ensure true breeding nature of the best clone identified/ developed through concerted research efforts need to be standardized. 


\section{THE ROLE OF BIOTECHNOLOGY}

The advances in biotechnology provide opportunities to significantly reduce cost of bio-fuel production by genetic manipulation of feed stocks in a way that improves biofuel yields. The development of genetically engineered sweet sorghums with enriched stalk juice and sugar yields and altered proportion of reducing and non-reducing sugars (in favor of reducing sugars) and efficient microbial fermenters of sugars into ethanol would significantly reduce cost of ethanol production. Similarly, the development of genetically engineered enzymes that can perform both starch hydrolysis and saccharification of cassava root tuber starch, will economize conversion of starch into ethanol. Reducing lignin in crop biomass without reduction in biomass yield will greatly improve bio-refinery efficiency. Genomics, proteomics, and metabolomics are being used to improve our understanding of and ability to manipulate the lignin biosynthesis pathway (Ortiz et al., 2006). For example, before processing, maize and sorghum stover is currently pretreated to convert ligno-cellulose into sugars but transgenic technologies may provide alternatives to pretreatment such as genetically engineered microbes that convert ligno-cellulose into sugars. In this regard, the potential of maize and sorghum brown mid-rib mutants that have altered lignin composition and ultra structure of secondary cell walls are being explored at Purdue University, West Lafayette, Indiana, USA. A considerably higher $(50 \%)$ yield of fermentable sugars after enzymatic hydrolysis of stover from certain maize and sorghum brown mid-rib mutants has been achieved (www.ct.ornl.gov/symposium/index_files/6Babstracts/ 6B_01.htm). Care must be taken, however, because changes in lignin properties may reduce biomass yield and resistance to pest, disease and lodging and/or alter stover nutritional value (Ortiz et al., 2006). Biotechnological tools hold promise for altering fatty acid composition (intractable trait for manipulation through conventional tools), one of the key traits for improving productivity of bio-diesel from jatropha and pongamia seed oils. Also, addressing more complex traits such as reducing toxins/anti-nutrients in jatropha oilseed cake for making it more valuable as animal feed, requires the use of biotechnological tools. The success stories on the use of molecular marker-assisted selection to improve the equally complex characteristic of oil concentration in maize kernels or fatty acid composition of soybean oils provide optimism for potential of biotechnological tools to improve the traits important for bio-fuel production from the biomass sources.

\section{POTENTIAL BENEFITS OF BIO-FUELS}

As bio-fuels are produced from biomass of crop plants, they offer enormous opportunities to improve the income levels of smallholder farmers in predominantly agrarian countries like India. At community level, farmers can cultivate energy crops that fetch more income while meeting their food needs. Given the bulkiness of most of the feed stocks, it is necessary to locate bio-fuel industries in rural areas where the feedstock crops are grown for ease of transportation. Local production of bio-fuels is projected to have a broad range of positive economic, social and environmental implications. At a national level, producing more bio-fuels will generate new industries, new technologies, new jobs and new markets assisting economic growth in rural areas besides reducing environmental pollution. Of the 1.7 million jobs in 2004 related to the renewable energy industry, almost a million of them were related to bio-fuels. For example, in Brazil, the ratio of jobs created from bio-fuel industry to those created from fossil fuel industry is $22: 1$ at $100 \%$ ethanol use and $6: 1$ at $25 \%$ ethanol use in transport vehicles (www.americanprogress.org). As bio-fuels are renewable, non-toxic and bio-degradable, they contribute to energy security and reducing environment pollution. The use of even $10 \%$ ethanol blends reduce green house gas emissions (GHG) by 12-19\% compared with conventional fossil petrol. Ethanol can be blended in low proportionsup to $25 \%$, with petrol for direct use in normal internal combustion engines without modification. Similarly, the use of diesel blended with fossil-diesel up to 20\% (B 20) results in substantial reduction of un-burnt hydrocarbons (by 30\%), carbon monoxide (by 20\%) and particulate matters (by 25\%) and negligible sulfur content in the emissions and requires very little or no modification of engine (Francis et al., 2005). Bio-diesel can be directly used to run power-drawn implements, tractors, pump sets for lift irrigation, and vehicles to transport agriculture produce to the markets. In Karnataka, state road transport corporation is running around 2500 busses with $7.7 \%$ ethanol blend and 300 busses with Pongmia biodiesel blend diesel for the past one year The Indian Railways has started to use the oil (blended with diesel fuel in various ratios) from the Jatropha plant to power its diesel engines with great success. Currently, the diesel locomotives that run from Thanjavur to Nagore section and Tiruchirapalli to Lalgudi, Dindigul and Karur sections in Tamil Nadu state run on a blend of Jatropha and diesel oil (http://en.wikipedia.org/wiki/Jatropha_In_India).

\section{ENERGY BALANCE OF BIO-FUELS}

The impact of bio-fuels on the global atmosphere and human and animal wild lives has been relatively small to date, particularly when compared with the environment and health costs of extracting, processing and burning of fossil fuels. However, as the production and use of biofuels increase, their impact on environment in relation to 
fossil fuels can be assessed. The climate impact of biofuels depends on their net energy balance (NEB) ratio (the energy contained in the bio-fuels to the fossil energy required to produce bio-fuel). This in turn depended on the energy intensity of feedstock production including the type of farming system and inputs used, processing, and transport. Though NEB of sugarcane is high (Table 2 ), there are reservation in political circle for its use as a feed stock in India as it viewed largely as a food crop.

Table 2. Energy balance of gasoline and ethanol by feedstock.

\begin{tabular}{lc}
\hline \multicolumn{1}{c}{ Feedstock } & $\begin{array}{c}\text { Energy output/fossil } \\
\text { energy input }\end{array}$ \\
\hline Sugarcane & 8.3 \\
Switch grass & 4.4 \\
Sugar Beet (European Union) & 1.9 \\
Corn (United States) & $1.3-1.8$ \\
Wheat (Canada) & 1.20 \\
Fossil fuel (Gasoline) & 0.8 \\
\hline Source: www.americanprogress.org &
\end{tabular}

There is a need to estimate energy balance of widely recognized bio-fuel feedstocks crops such as sweet sorghum, cassava, jatropha and pongamia, to justify research investments on improving and use of these crops for bio-fuel production.

\section{BIO-FUELS AND KYOTO PROTOCOL}

Under the Kyoto Protocol, Food and Agricultural Organization (FAO) supports the use of bio-fuels in agricultural practices and reforestation (rehabilitating waste lands and degraded lands with bio-fuel crops) so that developing countries may gain additional income from selling carbon credits, while improving the livelihoods of farmers through enhanced soil fertility and higher crop production. The Clean Development Mechanisms (CDM) under Kyoto Protocol provides opportunity to direct financing the projects that reduce GHG in developing countries. To date, however, no CDM projects related to liquid bio-fuels have been approved, likely because of overall lack of capacity for CDM project development in India, and limited availability of CDM baseline and monitoring methodology specifically developed for biofuels projects (Bakker 2006). The development and successful financing of CDM projects in future, requires establishing approved baseline and monitoring methodologies and capacity to develop and deal with bio-fuel projects.

\section{INSTITUTIONAL ARRANGEMENTS FOR BIO-FUEL RESEARCH}

Bio-fuel production poses a major new challenge to crop improvement and management research. For farmers to respond to market changes, they need multipurpose crops combining food, feed, fodder, fiber, and bio-fuel traits. Basic research on crop bio-fuels may best be undertaken by upstream academic organizations and the private sector. On the other hand, trait-based mining of genetic resources may be the most appropriate niche for public research organizations, particularly those of international agricultural research centers (IARC's) supported by the Consultative Group on International Agricultural Research $(\text { CGIAR })^{1}$. Clearly there are substantial financial incentives for private investment in developing new cultivars for bio-fuel production. Private investment, however, also threatens to result in the locking up of a large proportion of enabling technologies under various intellectual property protection mechanisms, as is already happening with, for example, critical enzymes in the bio-fuel production process. Therefore, the breeding of new crop cultivars for the bio-fuel market and development of new microbial/enzyme technologies provide an opportunity for a whole new paradigm in public-private partnerships for bio-fuel research and development. The IARC's such as the ICRISAT, IITA, CIAT, etc. may focus on genetic enhancement of plant genetic resources and feed into both public and private research and extension programs worldwide and may also serve as conduits of new knowledge and technology to small-scale farmers, particularly in resource-poor farming areas of the developing world (Ortiz et al., 2006). The IARC's together with national research programs have clear roles in finding suitable mechanisms to ensure that smallholder farmers (particularly those in resource-poor areas) can have sustainable benefits from this potentially lucrative biofuel market.

\section{Conclusion}

Implementing the government of India's policy to use 5\% (with plans to increasing it to $10 \%$ in a phased manner) ethanol-doped petrol and bio-diesel doped petro-diesel is a step towards reducing air pollution associated with the use of fossil-fuels and reducing dependency and fuelimport bill for the country. Investments in research and development and use of bio-fuels besides providing sustainable energy for increased agricultural production, offers enormous opportunities to developing world's smallholder farmers to diversify their livelihood options to augment their income levels. From an environmental standpoint, it offers an alternative lower carbon intensive development path, by offering ways to reduce GHG, while pursuing energy development goals and by taking advantage of the financial incentive embodied in the flexible mechanisms of Kyoto Protocol. Improving the energy value traits of widely cultivated food crops and identifying and genetic enhancement of water-saving 
non-food/new bio-fuel crops through research is necessary to mitigate trade-offs between food/fodder and energy security. Innovations in existing conversion technologies and/or development of new conversion technologies for efficient production of bio-fuels and the development of technologies that enable broadened use of byproducts of bio-fuel production chain are keys to attract investment in bio-fuel production. These along with building-up databases on energy balance of bio-fuel crops are essential to justify increased investments on research, development and the use of bio-fuels that have great potential in contributing to energy security of India.

\section{ACKNOWLEDGMENTS}

We gratefully acknowledge critical comments on the manuscript received from Dr. Mohan Saxena, Chair of the session on "Energy and agriculture with a special emphasis on bio-fuels" and Visiting Professor, Arid Land Research Center, Tottori University, Japan; and Mr. P Parthasarathy Rao, Senior Scientist (Economics), Global Theme on Institutions, Markets, Policy and Impacts, ICRISAT, Patancheru, India.

\section{REFERENCES}

Bharadwaj, A, Tongia R. and Arunachalam, V.S. (2007), Scoping technology options for India's oil security; Part I: Ethanol for petrol. Current Science, 92 (8): 1071-1077.

Badger, P.C. (2002). Ethanol from cellulose: a general review. In Trends in New Crops and New Uses (Janick J, ed.), (pp. 1720). ASHS Press, Alexandria, VA., USA.

Bakker, S.J.A. (2006). CDM and bio-fuels. Can the CDM assist bio-fuel production and deployment? Report of Energy research center of the Netherlands (ECN), No. ECN-E-06033. 31pp (www.ecn.nl/docs/library/report/2006/ e06033.pdf).

Carvalho, L.J., de Souza, C.B., Cascardo, C.R.B., Junior, J.C.M. and Campos, L. (2004) Identification and characterization of a novel cassava (Manihot esculenta Crantz) clone with high free sugar content and novel starch. Plant Molecular Biology, 56: 643-659.

Ceballos, H., Fregene, M., Lentini, Z., Sánchez, T., Puentes, Y.I., Pérez, J.C., Rosero, A. and Tofiño, A.P. (2006). Development and Identification of high-value cassava clones. Acta Horticulturae, 703: 63-70.

Francis, G., Edinger, R. and Becker, K. (2005). A concept for simultaneous wasteland reclamation, fuel production, and socio-economic development in degraded areas in India: need, potential and perspectives of jatropha plantations. Natural Resources Forum, 29: 12-24.

Hazell, P. and Pacauri, R.K. (2006). Bio-energy and Agriculture: Promises and Challenges- an Overview. Focus 14. In Bioenergy and Agriculture: Promises and Challenges (P. Lazell and R.K. Pachauri eds). International Food Policy Research Institute, Washington, USA and The Energy and Resources Institute, New Delhi, India.

Wani, S.P., Osman, M., Emmanuel, D'Silva and Sreedevi, T.K. (2006). Improved Livelihoods and environmental protection through bio-diesel. Plantations in Asia. Asian Biotechnology and Development Review, 8(2): 11-29.

Jorgenson, L.R. (1931). Brown mid-rib in maize and its lignage relations. Journal of American Society of Agronomy, 23: 549557.

Moreira J.R. 2006. Bio-energy and Agriculture: Promises and Challenges-Brazil's Experience with Bio-energy Focus 14. In Bio-energy and Agriculture: Promises and Challenges (P. Lazell and R.K. Pachauri eds). International Food Policy Research Institute, Washington, USA and The Energy and Resources Institute, New Delhi, India.

Nassar, N.M.A. and Marques, A.O. (2006). Cassava leaves as a source of protein. J. Food Agriculture and Environment, 4 (1): $187-188$.

Ortiz, R., Crouch, J.H., Iwanaga, M., Sayre, K., Warburton, M., Araus, J., Dixon, J., Bohn, M., Reddy, B.V.S., Ramesh, S. and Wani, S, (2006). Bio-energy and Agricultural Research for Development. Vision 2020 for Food Agriculture and the Environment, Focus 14, Policy Brief 7 of 12. International Food Policy Research Institute, USA and the Energy and Resources Institute, India.

Parikh, J. and Walia, A. (2002). Techno-economic Assessment of Bio-energy in India. Technology Information Forecasting and Assessment Council (TIFAC), Ministry of Science and Technology, Government of India, New Delhi.

Porter, K.S., Axtell, J.D., Lechtenberg, V.L. and Colenbrandu, V.F. (1978). Phenotype fiber composition and in vitro dry matter disappearance of chemically induced brown - mid-rib (bmr) mutants of sorghum. Crop Science, 18: 205-208.

Reddy, B.V.S., Ramesh, S., Reddy, P.S., Ramaiah, B., Salimath, P.M. and Rajashekar K. (2005). Sweet sorghum-a potential alternate raw material for bio-ethanol and bio-energy. International Sorghum and Millets Newsletter, 46: 79-86.

Sharma, S.D., Gupta, S.N., Khabiruddin, M. (1997). Cultivation of Jatropha curcus as a future source of hydrocarbon and other industrial products. In Bio-fuels and Industrial Products from Jatropha curcus (Gubitz GM, Mittelbach M and Trabi M, eds), Dbv-Verlag, Gaz, Austria. 